\title{
Taxonomic, Temporal, and Spatial Variations in Zooplankton Fatty Acid Composition in Puget Sound, WA, USA
}

\author{
Minna Hiltunen ${ }^{1}$ (D) Ursula Strandberg ${ }^{1} \cdot$ Michael T. Brett $^{2} \cdot$ Amanda K. Winans $^{3} \cdot$ David A. Beauchamp $^{4}$. \\ Miika Kotila ${ }^{1}$ · Julie E. Keister ${ }^{3}$
}

Received: 26 November 2020 / Revised: 27 May 2021 / Accepted: 10 June 2021 / Published online: 26 July 2021

(C) The Author(s) 2021

\begin{abstract}
Fatty acid (FA) content and composition of zooplankton in Puget Sound, Washington (USA) was studied to investigate the nutritional quality of diverse zooplankton prey for juvenile salmon (Oncorhynchus spp.) in terms of their essential fatty acid (EFA) content. The study focus was on eicosapentaenoic acid (EPA), docosahexaenoic acid (DHA), and arachidonic acid (ARA) as these are key FA needed to maintain growth and development of juvenile fish. The different zooplankton taxa varied in their FA composition. Much of the variation in FA composition was driven by 18:1 $\omega 9$ (a biomarker of carnivory), ARA, DHA, and FA characteristic of diatoms, which are linked to zooplankton diet sources. Gammarid and hyperiid amphipods contained the highest amount of EFA, particularly the gammarid amphipod Cyphocaris challengeri, while shrimp and copepods had much lower EFA content. Crab larvae, which are important prey for juvenile salmon in Puget Sound, had intermediate EPA + DHA content and the lowest DHA/EPA ratio, and were rich in diatom biomarkers. Temporal and spatial trends in zooplankton lipids were less apparent than the taxonomic differences, although the EFA content increased from spring to summer in Cancridae zoeae and the amphipod $C$. challengeri. These results on taxon-specific EFA content provide baseline information on the nutritional quality of zooplankton that can be applied in food web models. Combining zooplankton fatty acid data (quality) with taxon-specific zooplankton biomass data (quantity) enables development of new, sensitive indicators of juvenile fish production to help assess recent declines in salmon production in the Pacific Northwest and predict future adult returns.
\end{abstract}

Keywords Lipids · EPA · DHA · ARA · Biomarkers · Food quality

\section{Introduction}

Puget Sound is a deep estuarine fjord in Washington State, USA that consists of several distinct basins separated by natural sills and narrow straits that vary in salinity, temperature,

Communicated by David G. Kimmel.

Minna Hiltunen

minna.m.hiltunen@jyu.fi

1 Department of Environmental and Biological Sciences, University of Eastern Finland, P.O. Box 111, 80100 Joensuu, Finland

2 Civil and Environmental Engineering, University of Washington, P. O. Box 352700, Seattle, WA 98195, USA

3 School of Oceanography, University of Washington, P.O. Box 357940, Seattle, WA 98195, USA

4 Western Fisheries Research Center, U.S. Geological Survey, 6505 NE 65th Street, Seattle, WA 98115, USA and primary production (Moore et al. 2008). Zooplankton exhibit wide variation in biomass and community composition in Puget Sound, with differences occurring among basins, seasons, and years (Keister et al. 2017). Zooplankton, together with ichthyoplankton, are important food for many fish, including juvenile salmonids. Many stocks of anadromous Pacific salmon (Oncorhynchus spp.) on the west coast of the USA and Canada, and particularly from Puget Sound, have undergone steep population declines since the 1980s, including coho salmon (O. kisutch) and Puget Sound Chinook salmon (O. tshawytscha) (Zimmerman et al. 2015; Kendall et al. 2017; Ruff et al. 2017). In Puget Sound, one leading hypothesis for these declines is that the quantity or quality of important zooplankton prey has decreased over time (US Salish Sea Technical Team 2012). A recent study showed that the energy density and lipid composition of zooplankton prey varies taxonomically in the northern Salish Sea (Costalago et al. 2020; Weil et al. 2020); however, zooplankton quality 
in terms of fatty acid content has not been assessed in Puget Sound and may be quite different from other regions due to differences in oceanographic conditions, species composition, productivity, and organic matter sources.

In addition to meeting their energy demands, consumers need a balanced composition of essential nutrients in their diets to develop normally and achieve high growth rates. Many studies have demonstrated that polyunsaturated fatty acids (PUFA) are essential for the growth and development of crustaceans (Coutteau et al. 1997; Nghia et al. 2007) and fish (Ruyter et al. 2000; Glencross 2009). The omega-3 ( $\omega$-3) PUFAs eicosapentaenoic acid (EPA, 20:5 $\omega 3$ ) and docosahexaenoic acid (DHA, 22:6 $\omega 3$ ) and the omega-6 ( $\omega-6)$ PUFA arachidonic acid (ARA, 20:4 $\omega 6$ ) are considered essential fatty acids (EFAs) because they cannot be synthesized de novo and they are necessary for somatic growth, reproduction, immune responses, and osmoregulation of fish (Bell et al. 1997; Bell and Sargent 2003; Glencross 2009). Although the nutritional requirements of fish have mostly been studied in aquaculture settings, field studies also indicate the importance of dietary FAs; e.g., growth of herring larvae is linked to DHA availability in the field (Paulsen et al. 2014). Some freshwater and anadromous fish, including salmonids, have the ability to modify dietary PUFA, i.e., elongate and desaturate shorter-

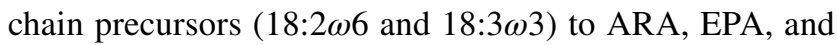
DHA (Glencross 2009); however, this modification pathway is generally inefficient, and a direct supply of dietary EFA results in higher growth rates than do the dietary short-chain precursors (Takeuchi and Watanabe 1982; Ruyter et al. 2000; Barry and Trushenski 2020). The same is true for marine zooplankton; e.g., copepods and euphausiids seem to be unable to convert short-chain precursors to EFA at physiologically significant rates (Bell et al. 2007).

Fatty acids are often used as biomarkers to investigate trophic interactions in aquatic systems because they are transferred from prey to predator tissues largely unmodified (Dalsgaard et al. 2003). Hence, certain fatty acids or their ratios may provide important insights into the resources that most strongly support upper trophic level production (Fraser et al. 1989; Galloway et al. 2014; Strandberg et al. 2018). For example, fatty acids indica-

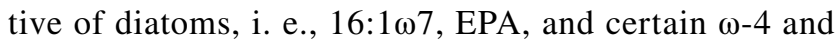
$\omega$-1 PUFAs (Jonasdottir 2019), have been shown to transfer through the marine food chain via zooplankton to fish (Fraser et al. 1989; St. John and Lund 1996). Dinoflag-

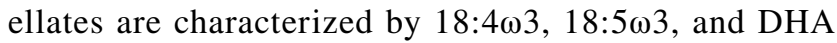
(Jonasdottir 2019). The DHA:EPA ratio has been used to infer the relative importance of diatoms vs. dinoflagellates at the base of marine food webs (Dalsgaard et al. 2003). DHA and 18:403 have also been used as trophic markers for flagellates in general (Dalsgaard et al. 2003). Allochthonous organic matter (OM), which is rich in longchain saturated fatty acids (SAFA; e.g., 22:0, 24:0, 26:0) originating in cuticular waxes of plant leaves (Hiltunen et al. 2019b), may contribute to basal food sources in estuarine systems. Bacteria and protozoans can also be important food resources for planktonic food webs, and iso- and anteiso-branched fatty acids and odd-chain SAFA are characteristic of bacteria (Kaneda 1991; Dalsgaard et al. 2003). In marine crustaceans, high $18: 1 \omega 9 / 18: 1 \omega 7$ ratio has been linked to carnivory (Falk-Petersen et al. 2000; Stevens et al. 2004; El-Sabaawi et al. 2009).

Although the fatty acid composition of consumers is modified by diet, taxon-specific characteristics are also well documented (Persson and Vrede 2006; Budge et al. 2002; Hiltunen et al. 2015). For example, marine copepods are characterized by the 20 and 22 carbon chain $\left(\mathrm{C}_{20}\right.$ and $\mathrm{C}_{22}$ ) monounsaturated fatty acids (MUFA) and fatty alcohols they synthesize to store lipids as wax esters (Lee et al. 2006). Furthermore, the copepod Limnocalanus macrurus, which occurs both in fresh and brackish water environments, produces conspicuous long-chain PUFA $\left(\mathrm{C}_{24}\right.$ and $\mathrm{C}_{26}$ ) that are transferred to planktivorous fish (Hiltunen et al. 2014). Fatty acid profiles of prey have also been used to quantitatively infer fish diets based on their fatty acid composition (Budge et al. 2012; Happel et al. 2016).

The diet of Chinook and coho salmon during their early marine residence in Puget Sound is composed of euphausiids, crab larvae, hyperiid and gammarid amphipods, and large copepods, with an increasing proportion of 0-age fish as juvenile salmon grow larger (Simenstad 1982; Duffy et al. 2010; Gamble 2016). The potential role of prey quality in the decline of salmon production in Puget Sound has not been addressed due to lack of data on nutritional quality of zooplankton prey. As a part of the Salish Sea Marine Survival Project, we sampled zooplankton throughout Puget Sound and adjacent waters for analysis of seasonal, spatial, and taxon-specific fatty acid composition and EFA content of zooplankton. The goal of this study was to evaluate the nutritional quality of diverse zooplankton taxa based on their fatty acid content, especially in regard to the nutritional requirements of juvenile salmon, and to explore trophic linkages in the planktonic food web using fatty acid biomarkers. We hypothesized that zooplankton taxa differ in their fatty acid composition, the differences are linked to feeding modes and diet sources, and that there are differences in the quality of zooplankton as prey for higher trophic level consumers determined by their EFA content.

\section{Methods}

Zooplankton samples $(n=274)$ from the major regions of Puget Sound (Whidbey Basin, Central Basin, South Sound, Hood Canal, Admiralty Inlet) and adjacent waters 
of northern Washington (San Juan Islands and Bellingham Bay) were collected for lipid analyses from March to October 2017 (Fig. 1). An additional 35 samples were collected from a few locations in June-July 2015 and 12 samples from July-September 2018 using the same methods except as noted below. Most samples were collected using $60-\mathrm{cm}$-diameter, $335-\mu \mathrm{m}$ mesh bongo nets towed obliquely through approximately the upper $30-180 \mathrm{~m}$ of the water column. Of these 321 samples, 225 were collected during the day and 96 were collected at night; nighttime samples were ideal for collecting larger taxa, such as adult euphausiids and amphipods, which are rarely in the upper water column during the day. Some daytime tows were deep enough to collect organisms that undergo diel vertical migration during the day. Various other collection techniques were used for a minority of the samples: four crab and ostracod samples were collected with a light trap at night; 12 fish, crab, and shrimp samples were collected in the upper $3 \mathrm{~m}$ during the day in a surface trawl; and 7 amphipod and shrimp samples were collected during the day and at night with a $200-335-\mu \mathrm{m}$ mesh, $0.25-\mathrm{m}^{2} \mathrm{Hyd}-$ robios Multinet. The nets were gently rinsed into coolers, chilled with ice packs, and aerated to keep zooplankton alive until sorting later the same day or, when live sorting
Fig. 1 Map of the sampling stations for zooplankton fatty acid composition in Puget Sound and adjacent waters of northern Washington in 2017-2018

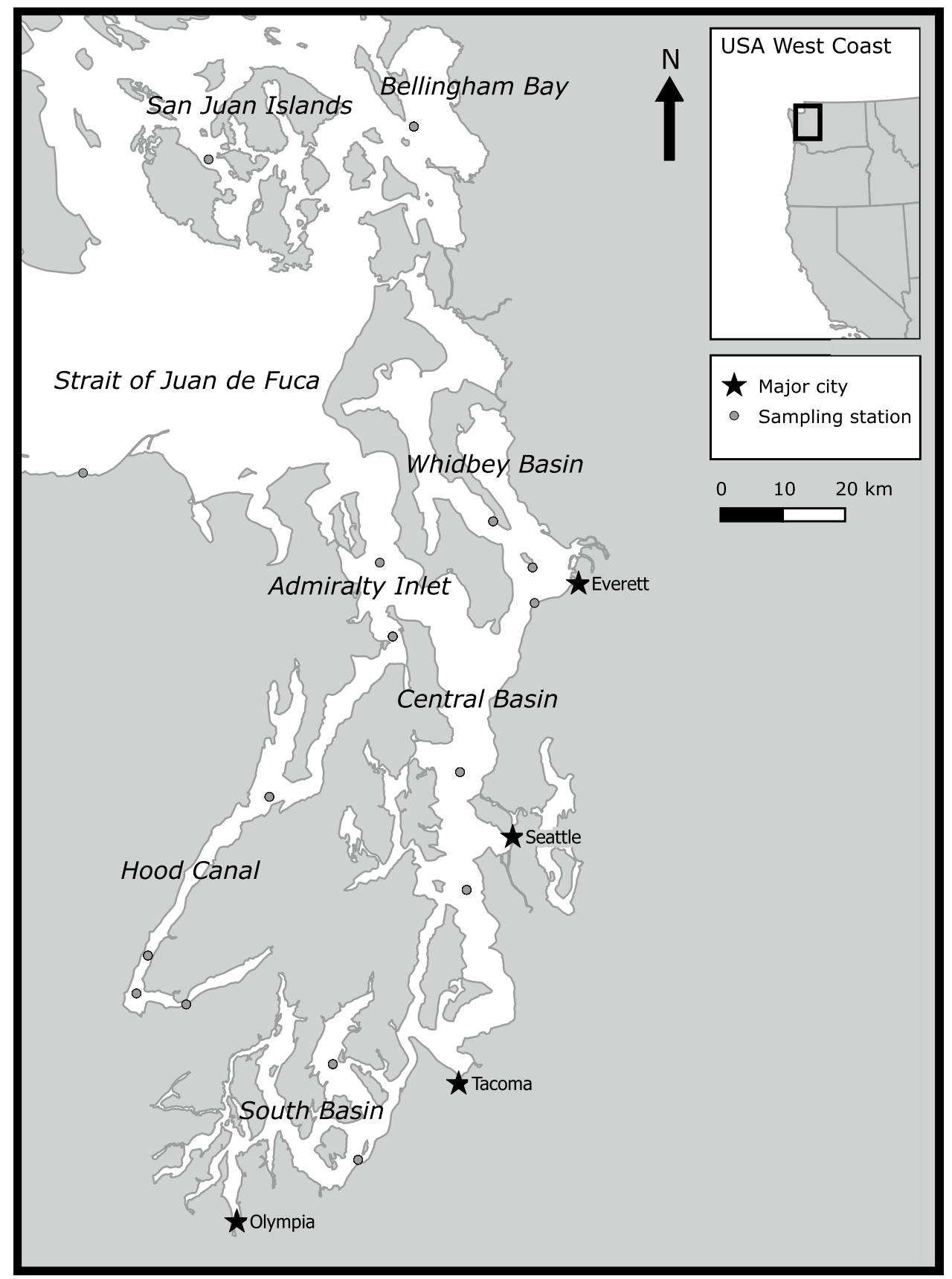


was not possible, the bulk zooplankton samples were frozen $\left(-70{ }^{\circ} \mathrm{C}\right)$ for up to 1 month then partially thawed to separate by taxon (this included a few samples in 2017 and all samples collected in 2015).

Zooplankton, including ichthyoplankton, sorted for fatty acid analyses were grouped by species or family where species identification was not practical. In total, 13 broad taxonomic groups containing over 60 taxa were collected and stored frozen $\left(-70{ }^{\circ} \mathrm{C}\right)$ until analysis. It was not practical to separate different life stages of most taxa, apart from crab zoeae, megalopae, and euphausiids (all of which were subadults or adults). Of the 20 fish samples most were larval fish, but three were juveniles and two postlarvae.

The samples were freeze-dried, weighed, and extracted with 2:1 chloroform-methanol following Folch et al. (1957). The fatty acids were transformed into fatty acid methyl esters (FAMEs) by acid-catalyzed transesterification. The FAMEs were dissolved in hexane, and run through a Gas Chromatograph coupled with a Flame Ionization Detector (GC-FID; Hewlett Packard HP6890) with an Agilent DB-23 column (30 $\mathrm{m} \times 0.25 \mathrm{~mm} \times 0.15 \mu \mathrm{m})$. Helium was used as a carrier gas with an average velocity of $25 \mathrm{~cm} \mathrm{~s}^{-1}$. A subset of samples was also run with a Gas Chromatogram-Mass Spectrometer (GC-MS; 2017 samples: Shimadzu QP2010 Plus, 2015 samples: Agilent $6890 \mathrm{~N}$ and 5973 N) using the same column and temperature program to confirm peak identifications. FAMEs were quantified using a dilution series of a fatty acid standard mixture (GLC-68D, Nu Chek Prep.). See the technical report by Hiltunen et al. (2019a) for a more detailed description of the sample collection and processing in 2017. Individual FAMEs were identified based on their mass spectra.

Differences in percent fatty acid composition of zooplankton among taxa, seasons (spring: March-April, summer: May-July, fall: August-October), and regions were tested with Permutational Multivariate Analysis of Variance (PERMANOVA). Taxon, region, and season were treated as fixed factors. PERMANOVA was only performed on taxa with $\mathrm{n}>7$, and regions with $\mathrm{n}>10$ (total $n=302$ ). PERMANOVA was run with 4999 permutations, type III sum of squares, and permutation of residuals under a reduced model. We used PERMDISP to test for differences in withingroup multivariate dispersion to evaluate the reliability of the PERMANOVA results. Differences in fatty acid composition were visualized with a non-metric multidimensional scaling (NMDS) ordination plot. The multivariate statistics were conducted on Bray-Curtis distances. We used the sum of PUFA unique for diatoms (DIFA, i.e., the sum of 16:2 14 ,

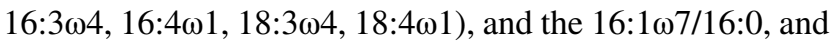
DHA/EPA ratios as biomarkers for diatoms, with high DIFA and 16:1 $17 / 16: 0$ ratios and low DHA/EPA ratios indicating

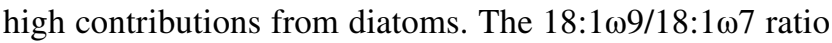
was used as index of carnivory, and the sum of odd-chain and iso- and anteiso-branched fatty acids (BAFA) was used as an indicator of bacterial and microbial loop contributions. We evaluated the performance of different diatom indices

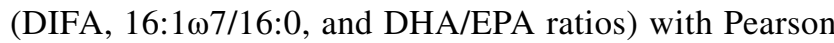
correlations.

We did not measure dry weights for the 2015 samples, and hence have only used these samples in the plots and analyses based on FA proportions. Thus, the reported EFA contents ( $\mu \mathrm{g} \mathrm{mg} \mathrm{DW} \mathrm{DW}^{-1}$ ) are only based on 2017 samples. Differences in EPA + DHA and ARA concentrations among zooplankton taxa were tested with a non-parametric Kruskal-Wallis $\mathrm{H}$ test because the data were not normally distributed, even with common transformations. Kruskal-Wallis $\mathrm{H}$ test was also used for seasonal differences in EFA content for the five most abundant taxa in our samples: Cancridae zoeae and megalopae, the amphipods Themisto pacifica and Cyphocaris challengeri, and the euphausiid Euphausia pacifica. Also, Cancridae crab larvae and the euphausiid Euphausia pacifica were tested for differences in EFA content among life-history stages. We also compared zooplankton and ichthyoplankton EFA content to the nutritional requirements of Atlantic salmon (Salmo salar) and rainbow trout (Oncorhynchus mykiss) proposed by the Food and Aquaculture Organization of the United Nations (FAO) (FAO 2020a,b). These threshold values are based on aquaculture studies, and therefore may not correspond directly to nutritional requirements in the field or for other salmonids, but they provide a useful baseline to compare our EFA results against. Statistical analyses were conducted with IBM SPSS 24 and PRIMER 7 with the PERMANOVA + add-on. The map was drawn with QGIS (QGIS Development Team 2016).

\section{Results}

We used PERMANOVA to investigate how taxonomic identity, season, and sampling location affected zooplankton fatty acid composition. The fatty acid percent composition differed among the broad taxonomic groups of zooplankton (PERMANOVA, $\mathrm{F}_{6,224}=15.465, \mathrm{p}<0.001$; Table 1 and Fig. 2), with taxonomic group explaining $41 \%$ of the variation in the data. The effects of season and region were also significant, but these variables (and their two-way interaction) only explained a small fraction of the variance in the data (Table 1), indicating that taxonomic differences were the major driver of patterns in fatty acid composition. Pairwise comparisons of the broad taxonomic groups indicated that all groups differed from each other $(t=2.170-10.562$, $\mathrm{p}<0.002$ in all; Online Resource 2); however, the PERMDISP routine identified differences in dispersion within the groups (Online Resource 2). More specifically, mysids had lower dispersion than gammarids, hyperiids, and fish (probably due to a lower sample size), while dispersion was 
Table 1 The effect of broad taxonomic group, season (spring, summer, fall), and region on zooplankton fatty acid composition according to PERMANOVA

\begin{tabular}{llllccl}
\hline Term & df & SS & MS & Pseudo-F & $p$ & $\mathrm{R}^{2}$ \\
\hline Broad group & 6 & 13,313 & 2219 & 15.465 & $<0.001$ & 41 \\
Region & 4 & 1201 & 300 & 2.093 & 0.005 & 3 \\
Season & 1 & 590 & 590 & 4.111 & 0.003 & 12 \\
Broad group $\times$ region & 29 & 4595 & 158 & 1.104 & 0.219 & 1 \\
Broad group $\times$ season & 11 & 2098 & 191 & 1.329 & 0.078 & 2 \\
Region $\times$ season & 7 & 1579 & 226 & 1.573 & 0.028 & 2 \\
Broad group $\times$ region $\times$ season & 16 & 2510 & 157 & 1.094 & 0.287 & 1 \\
\hline
\end{tabular}

The amount of explained variation $\left(\mathrm{R}^{2}\right)$ was calculated from estimates of components of variation higher in gammarids than in shrimp and euphausiids (Online Resource 3). Mysids also overlapped significantly with the other taxa in the NMDS plot (Fig. 2), which together with large differences in dispersion makes it difficult to discern if the fatty acid composition of mysids differed from the other groups. Gammarids, however, formed a distinct group in the NMDS with little overlap with euphausiids and shrimp, indicating that the difference in fatty acid composition between these groups is reliable despite the small differences in dispersion.

A large fraction of the among- and within-group variation in fatty acid percent composition was driven by $18: 1 \omega 9$,

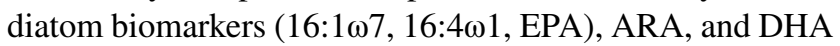
(Fig. 2). Gammarids, and especially Cyphocaris challengeri, were rich in 18:109 (Table 2 and Online Resource 1). This was also reflected in gammarids having a very high 18:1 $\omega 9 / 18: 1 \omega 7$ ratio. Copepods (mainly Calanus pacificus) had high proportions of DHA and 24:1 $\omega 9$, and surprisingly, similar or even lower levels of $\mathrm{C}_{20}+\mathrm{C}_{22}$ MUFA than the other groups (Table 2). Cephalopods, polychaetes, and pteropods had $>5 \% \mathrm{C}_{20}+\mathrm{C}_{22}$ MUFA, but only two samples of each were analyzed (Online Resource 1). Of the hyperiid amphipods, the genera Hyperoche and Hyperia had higher proportions of ARA than any other taxa $(10.0 \pm 1.7 \%$, mean \pm SD), while Themisto pacifica and Primno macropa had a lower proportion of ARA $(2.4 \pm 2.1 \%)$ (Table S3). Crab larvae had the lowest proportion of DHA, a low DHA/EPA

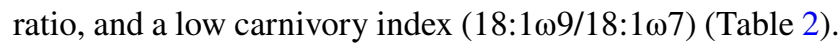
Crab larvae were rich in diatom biomarker fatty acids, and there was also variation among taxa with the Pinnotherid crab Fabia subquadrata having higher values for diatom biomarkers than most other crab taxa (Online Resource 1). Among krill, Euphausia pacifica had a similar fatty acid composition to Thysanoessa spp. (comprised mainly of T. raschii with some $T$. spinifera). In shrimp, Pasiphaea pacifica had a different fatty acid composition from the other taxa, specifically a higher proportion of $18: 1 \omega 9$ and consequently a higher carnivory index $(18: 1 \omega 9 / 18: 1 \omega 7)$ (Online
Fig. 2 Non-metric multidimensional scaling (NMDS) ordination of fatty acid percent composition in Puget Sound zooplankton $(\mathrm{n}=321)$. The final stress for 2-D solution was 0.18 . Fatty acids that correlate $(r>0.4)$ with either of the axis are shown as vectors

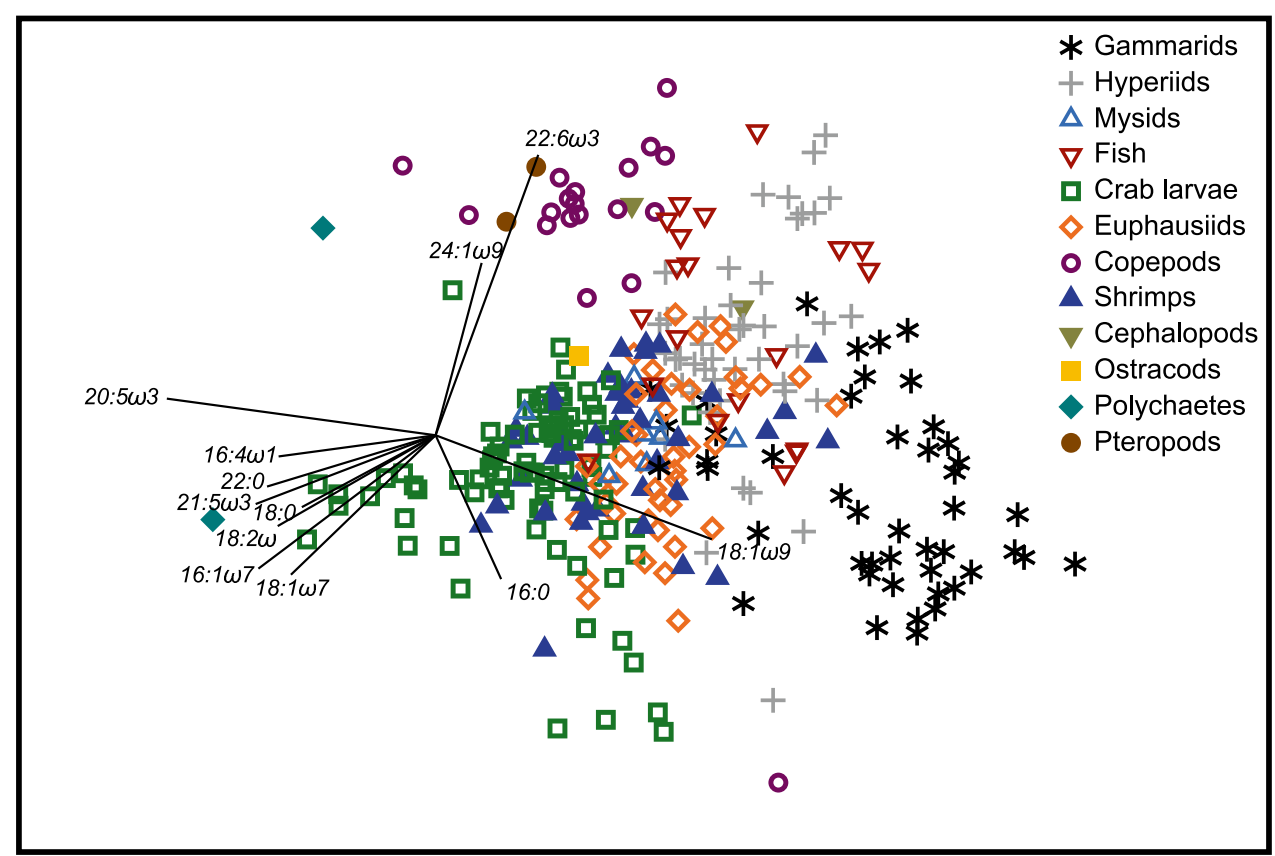

NMDS1 
Table 2 Fatty acid percent composition $(m e a n \pm S D)$ and trophic indices in broad taxonomic groups $(n>2)$ of Puget Sound zooplankton

\begin{tabular}{|c|c|c|c|c|c|c|c|c|c|c|c|c|c|c|c|c|c|c|c|c|c|c|c|c|}
\hline \multirow{3}{*}{$\frac{\text { Fatty acid }}{14: 0}$} & \multirow{2}{*}{\multicolumn{3}{|c|}{$\frac{\text { Gammarids }}{\mathrm{n}=46}$}} & \multirow{2}{*}{\multicolumn{3}{|c|}{$\begin{array}{l}\text { Hyperiids } \\
\mathrm{n}=44\end{array}$}} & \multirow{2}{*}{\multicolumn{3}{|c|}{$\begin{array}{l}\text { Mysids } \\
\mathrm{n}=8\end{array}$}} & \multirow{2}{*}{\multicolumn{3}{|c|}{$\frac{\text { Fish }}{\mathrm{n}=20}$}} & \multirow{2}{*}{\multicolumn{3}{|c|}{$\frac{\text { Crab larvae }}{\mathrm{n}=87}$}} & \multirow{2}{*}{\multicolumn{3}{|c|}{$\frac{\text { Euphausiids }}{\mathrm{n}=45}$}} & \multirow{2}{*}{\multicolumn{3}{|c|}{$\frac{\text { Copepods }}{\mathrm{n}=19}$}} & \multirow{2}{*}{\multicolumn{3}{|c|}{$\begin{array}{l}\text { Shrimps } \\
\mathrm{n}=45\end{array}$}} \\
\hline & & & & & & & & & & & & & & & & & & & & & & & & \\
\hline & 7 & \pm & 1.2 & 1 & \pm & 1.1 & 3 & \pm & 1.9 & 1.9 & \pm & 1.1 & 3.6 & \pm & 1.8 & 3.7 & \pm & 1.7 & 5.3 & \pm & 3.0 & 2.3 & \pm & \\
\hline $6: 0$ & .2 & \pm & 2.4 & 5.4 & \pm & 3.6 & .6 & \pm & 3.2 & 22.8 & \pm & 2.3 & 17.5 & \pm & 3.3 & 22.8 & \pm & 2.9 & 8.1 & \pm & 3.6 & 20.2 & \pm & 2.5 \\
\hline 6: & 2 & \pm & 0.1 & 7 & \pm & 0.9 & 0.3 & \pm & 0.1 & 3 & \pm & 0.2 & 0.3 & \pm & 0.2 & 0.3 & \pm & 0.2 & 0.1 & \pm & 0.0 & 0.2 & \pm & 0.2 \\
\hline $6: 1$ & 3.8 & \pm & 1.9 & 3.2 & \pm & 2.1 & 4.5 & \pm & 1.1 & 3.2 & \pm & 1.7 & 6.7 & \pm & 3.3 & 4.7 & \pm & 2.2 & 4.9 & \pm & 1.8 & 4.9 & \pm & 1.8 \\
\hline$: 2$ & .5 & \pm & 0.3 & 0.7 & \pm & 0.4 & 0 & \pm & 0.3 & & \pm & 0. & 0.7 & \pm & 0.5 & 1.1 & \pm & 0.6 & 1.2 & \pm & 0.5 & 0.4 & \pm & 0.3 \\
\hline & & \pm & 0.5 & 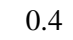 & \pm & 0.4 & 0 & \pm & 0.4 & & \pm & 0. & 0.7 & \pm & 0.8 & 0.7 & \pm & 0.5 & 1.4 & \pm & 1.0 & .2 & \pm & 0.3 \\
\hline 6: & & \pm & 0.3 & 0 & \pm & 0.4 & 0 & \pm & 0.6 & & \pm & 0 . & 1.2 & \pm & 1.2 & 0.9 & \pm & 0.6 & 1.3 & \pm & 1.2 & 4 & \pm & 0.5 \\
\hline 8 & & \pm & 2.0 & 5.6 & \pm & 2.4 & 3 & \pm & 1.3 & 7 & \pm & 2. & 9.2 & \pm & 3.4 & 3 & \pm & 1.5 & 3.0 & \pm & 1.1 & 4 & \pm & 2.6 \\
\hline & .1 & \pm & 6.9 & 1.4 & \pm & 2.2 & 8 & \pm & 1.6 & 7.6 & \pm & 3.2 & 6.1 & \pm & 2.0 & 9.1 & \pm & 2.0 & 1.6 & \pm & 0.9 & .7 & \pm & 3.8 \\
\hline & & \pm & 1.1 & 3 & \pm & 1.1 & 3. & \pm & 1.2 & 4 & \pm & 1.2 & 6.7 & \pm & 1.8 & 6 & \pm & 1.3 & 1.2 & \pm & 0.6 & .1 & \pm & 1.8 \\
\hline & & \pm & 1.5 & 1 & \pm & 0.6 & 0 & \pm & 0.2 & 0 & \pm & 0. & 0 . & \pm & 0.2 & 1 & \pm & 0.6 & 0.6 & \pm & 0.2 & 0.8 & \pm & 0.4 \\
\hline & & \pm & 0.5 & 1. & \pm & 1.0 & 1.0 & \pm & 0.3 & 1 & \pm & 1.0 & 1.2 & \pm & 0.9 & 1.9 & \pm & 1.6 & 1. & \pm & 1.4 & 0.8 & \pm & 0.6 \\
\hline & & \pm & 1. & 1 & \pm & 0.7 & 1 & \pm & 0. & & \pm & 0.6 & 0.9 & \pm & 0.3 & 0 & \pm & 0.5 & 0.7 & \pm & 0.8 & .0 & \pm & 0.7 \\
\hline & & \pm & 1.3 & & \pm & 3 & & \pm & 0.6 & & \pm & 1.4 & .2 & \pm & 0.5 & 1.3 & \pm & 0.5 & 0.5 & \pm & .2 & .6 & \pm & 1.0 \\
\hline ( & & 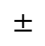 & 5.6 & 18.7 & \pm & 2.5 & 2 & \pm & 4.8 & 16. & \pm & 4.0 & 2 & \pm & 4.4 & 21.7 & \pm & 2.9 & & \pm & 3.6 & 22.8 & \pm & 3.9 \\
\hline 22 & & 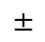 & 1.4 & & \pm & 0.3 & & \pm & 0.7 & & \pm & & & \pm & 4 & & \pm & 0.4 & & \pm & 1.6 & & \pm & 0.9 \\
\hline & & \pm & & & \pm & 0.1 & & \pm & & & \pm & & & $\perp$ & 0.3 & & \pm & 0.2 & & \pm & 0 & & $\perp$ & .3 \\
\hline & & \pm & 4.5 & & \pm & 3 & 14.1 & \pm & 2.2 & 2 & \pm & 7.5 & & \pm & 3.8 & 14.6 & \pm & 4.9 & 26.5 & \pm & .1 & 13.7 & \pm & 4.0 \\
\hline & & \pm & & & \pm & 0 & & \pm & 0.1 & & \pm & 0.5 & 0.1 & \pm & 0 & & \pm & 0 & 1.5 & \pm & 0 & 0.3 & \pm & 0.4 \\
\hline & & \pm & 0.8 & & \pm & 0. & 1.6 & \pm & 0.4 & & \pm & 0.8 & 1 & \pm & 0 & & \pm & 0 . & 1.3 & \pm & 0.4 & 1.8 & \pm & 1.0 \\
\hline & & \pm & 1.0 & 1.8 & \pm & 1 & 2.1 & \pm & 1.2 & 1 & \pm & 0.6 & 2 & \pm & 2 & 2 & \pm & 1.6 & 4.2 & \pm & 2.5 & 2 & \pm & 1.2 \\
\hline $16 \cdot 107$ & & \pm & 0.1 & 0.2 & \pm & 0 . & 0 & \pm & 0.1 & 0 & \pm & 0.1 & 0.4 & 1 & 0.2 & 0.2 & \pm & 0.1 & 0.0 & \pm & 0.2 & .2 & \pm & 0.1 \\
\hline 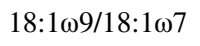 & 9 & \pm & 8.4 & 3.4 & \pm & 1. & 2 & \pm & 0.8 & 2 & \pm & 0.8 & 1.0 & \pm & 0.4 & 1.5 & \pm & 0.4 & 1 & \pm & 1.2 & .2 & \pm & 0.9 \\
\hline DHA/FPA & & \pm & 0. & 1 & \pm & 0.2 & 0 & \pm & 0.2 & 1 & \pm & 0.6 & 4 & \pm & 0.2 & 7 & \pm & 0.3 & 3 & \pm & 0.3 & .6 & \pm & 0.2 \\
\hline 年 & & \pm & $\cdot 1$ & 5.2 & \pm & 1.5 & 2.4 & \pm & 1. & 1.6 & \pm & 1.2 & 2.5 & $\perp$ & 0.7 & 1.2 & \pm & 1.0 & 2.9 & \pm & 2.9 & 2.2 & \pm & 1.8 \\
\hline
\end{tabular}

Only fatty acids with mean contribution $>1 \%$ in at least one taxa are included. See Online Resource 1 for the full FA profiles. BAFA bacterial

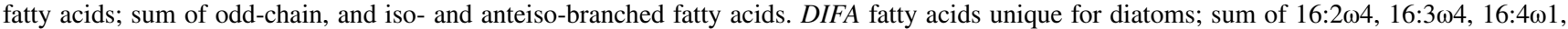
$18: 3 \omega 4$, and $18: 4 \omega 1$

Resource 1). Crangonidae shrimp showed high levels of diatom biomarkers in some samples, and high proportions of ARA, DHA, and bacterial biomarkers in others. Consistent with the results for the whole fatty acid profiles, we did not observe clear within-group seasonal differences in the fatty acid indices (data not shown).

Fatty acids unique for diatoms (DIFA, sum of 16:2 $\omega 4$, $16: 3 \omega 4,16: 4 \omega 1,18: 3 \omega 4,18: 4 \omega 1)$ formed up to $11.7 \%$ of the total fatty acids in zooplankton, and bacterial fatty acids (BAFA) up to 5.4\% . Apart from a low proportion of 22:0 $(0.2 \pm 0.2 \%)$, we did not find long-chain saturated fatty acids indicative of terrestrial OM utilization in zooplankton (Online Resource 1). The highest DHA/EPA ratio was found in fish $(1.5 \pm 0.6)$ and the lowest in crab larvae $(0.4 \pm 0.2)$ (Table 2). The 16:1 $\omega 7 / 16: 0$ ratio correlated strongly with DIFA $(\mathrm{r}=0.631, \mathrm{p}<0.001, \mathrm{n}=321)$ and the DHA/EPA ratio $(\mathrm{r}=-0.503, \mathrm{p}<0.001, \mathrm{n}=321)$. However, the values for $16: 1 \omega 7 / 16: 0$ were rather low in our data, with only two sam-

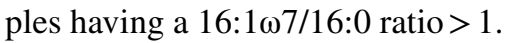

For the 2017 samples, we estimated the total fatty acid and EFA content and potential quality of each zooplankton taxon as prey for higher trophic level consumers. Total fatty acid content (a proxy for lipid content) differed among the broad taxonomic groups (Kruskal-Wallis, $H=56.062$, $p<0.001, n=279$, among the species with sufficient sample size available; Fig. 3). Gammarids had higher total fatty acid content $\left(121 \pm 79 \mu \mathrm{g} \mathrm{mg} \mathrm{DW}{ }^{-1}\right)$ than the other taxa. Hyperiid amphipods $\left(71 \pm 28 \mu \mathrm{g} \mathrm{mg} \mathrm{DW}{ }^{-1}\right)$ and euphausiids $\left(86 \pm 56 \mu \mathrm{g} \mathrm{mg} \mathrm{DW}{ }^{-1}\right)$ had lower total fatty acid content than gammarids, but higher than shrimp $\left(44 \pm 19 \mu \mathrm{g} \mathrm{mg} \mathrm{DW}^{-1}\right)$. Fish, mysids, crab larvae, and copepods had an intermediate total fatty acid content (Fig. 3). There were significant differences in the zooplankton EPA + DHA content among the broad taxonomic groups (Kruskal-Wallis, $H=48.69$, $p<0.001, n=279$; Fig. 4a). The highest EPA + DHA content was found in gammarid amphipods $(32 \pm 18 \mu \mathrm{g} \mathrm{mg}$ $\mathrm{DW}^{-1}$, mean $\pm \mathrm{SD}$ ) while shrimp had the lowest $\mathrm{EPA}+\mathrm{DHA}$ content $\left(16 \pm 7 \mu \mathrm{g} \mathrm{mg} \mathrm{DW}{ }^{-1}\right)$ (Fig. 4a). The hyperiid and 
Fig. 3 Total fatty acid content (a proxy for lipid content) of zooplankton and ichthyoplankton in Puget Sound and adjacent waters of northern Washington from March to October of 2017. The box represents the 25 th to 75 th quartile of the data; line is the median; and whiskers represent the maximum and minimum values, omitting the outliers (asterisks; more than 1.5 box lengths from the median). Different letters denote significant differences in Kruskal-Wallis post-hoc test; taxa with few replicates $(n=1-2)$ were not tested for differences and individual values for these are plotted with round markers

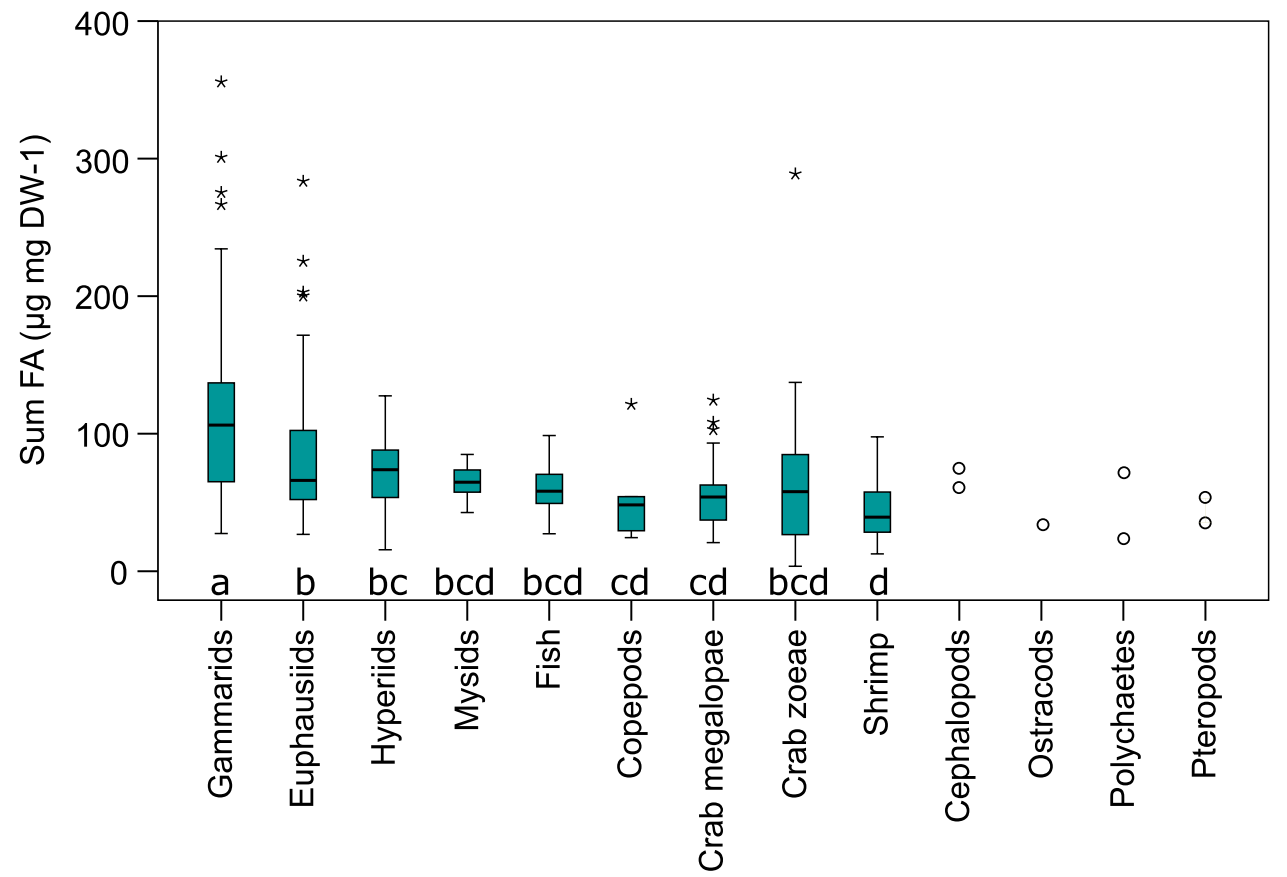

gammarid amphipods contained significantly more ARA than the other taxa $(2.2 \pm 1.7$ and $1.4 \pm 0.6 \mu \mathrm{g}$ ARA mg $\mathrm{DW}^{-1}$, respectively) $(H=105.07, p<0.001, n=279$; Fig. 4b). Copepods were especially poor in ARA with only $0.2 \pm 0.1 \mu \mathrm{g}$ ARA mg DW ${ }^{-1}$.

A portion of the within-group variation in zooplankton EFA content was related to differences among species and families (Fig. 5). Among hyperiid amphipods the genera Hyperoche and Hyperia had higher ARA content than the other taxa. Of the crab larvae, Paguridae zoeae seemed to have higher ARA and EPA + DHA content than some of the other zoeae taxa. Among the euphausiids, T. spinifera had higher EFA content than the other taxa. The DHA/EPA ratio also varied among the species and families of zooplankton (Fig. 6). The Pasiphaea pacifica shrimp had a higher DHA to EPA ratio than other shrimp. The DHA/EPA ratio was highest in larval fish, but also varied substantially.

We compared these EFA values to the nutritional requirements of Atlantic salmon and rainbow trout in aquaculture systems proposed by FAO (10-15 $\mu \mathrm{g}$ EPA + DHA mg DW ${ }^{-1}$, $5 \mu \mathrm{g}$ ARA mg DW ${ }^{-1}$ ). Excluding some crab larvae and Crangonidae shrimp, the zooplankton and ichthyoplankton taxa exceeded the minimum requirement for EPA + DHA (Fig. 5a). However, the requirement for ARA was not met in most of the taxa we sampled (Fig. 5b).

We also studied seasonal variation in EFA content in the five taxa for which we had the best temporal coverage: Cyphocaris challengeri, Themisto pacifica, Cancridae zoeae and megalopae, and Euphausia pacifica. The EFA content increased from spring to summer in $C$. challengeri (EPA + DHA: $\mathrm{H}=10.70, \mathrm{p}=0.003)$ and Cancridae zoeae
(EPA + DHA: $\mathrm{H}=6.68, \mathrm{p}=0.04$; ARA: $\mathrm{H}=6.28, \mathrm{p}=0.04$ ), while the other taxa did not exhibit significant differences among seasons ( $p>0.05$; Fig. 7). We also investigated the differences in EFA content among life-history stages of Cancridae crab larvae and the krill Euphausia pacifica. The EFA content of Cancridae crab larvae was lower in the early zoea stages (I-III) than in late-stage zoea and megalopa (EPA + DHA: $\mathrm{H}=14.55, \mathrm{p}=0.002$; ARA: $\mathrm{H}=8.26$, $\mathrm{p}=0.04$; Online Resource 4). The EFA content of krill Euphausia pacifica did not differ between juveniles and adults ( $\mathrm{p}>0.05$; Online Resource 4).

\section{Discussion}

We analyzed the fatty acid composition of zooplankton and ichthyoplankton collected from different regions of Puget Sound from March to October. There were significant differences in both fatty acid percent composition and nutritional quality (based on EFA content) of Puget Sound zooplankton. The fatty acid composition was mainly driven by taxonomic differences, which explained almost half of the variation in the data.

Temporal and spatial trends in fatty acid composition were significant but weaker than taxonomic differences, possibly because the major taxonomic groups were not systematically sampled in all regions throughout the whole time period. However, when comparing EFA content among seasons in the five most abundant taxa in our samples, Cancridae zoeae and the amphipod Cyphocaris challengeri exhibited seasonal differences, whereas Cancridae megalopae, 
Fig. 4 a Eicosapentaenoic acid + docosahexaenoic acid $(\mathrm{EPA}+\mathrm{DHA})$ and $\mathbf{b}$ arachidonic acid (ARA) content $(\mu \mathrm{g} \mathrm{mg}$ $\mathrm{DW}^{-1}$ ) of zooplankton in Puget Sound and adjacent waters of northern Washington from March to October of 2017. Box and whisker plots as described in Fig. 3. Different letters denote significant differences in Kruskal-Wallis post-hoc test; taxa with few replicates $(n=1-2)$ were not tested for differences
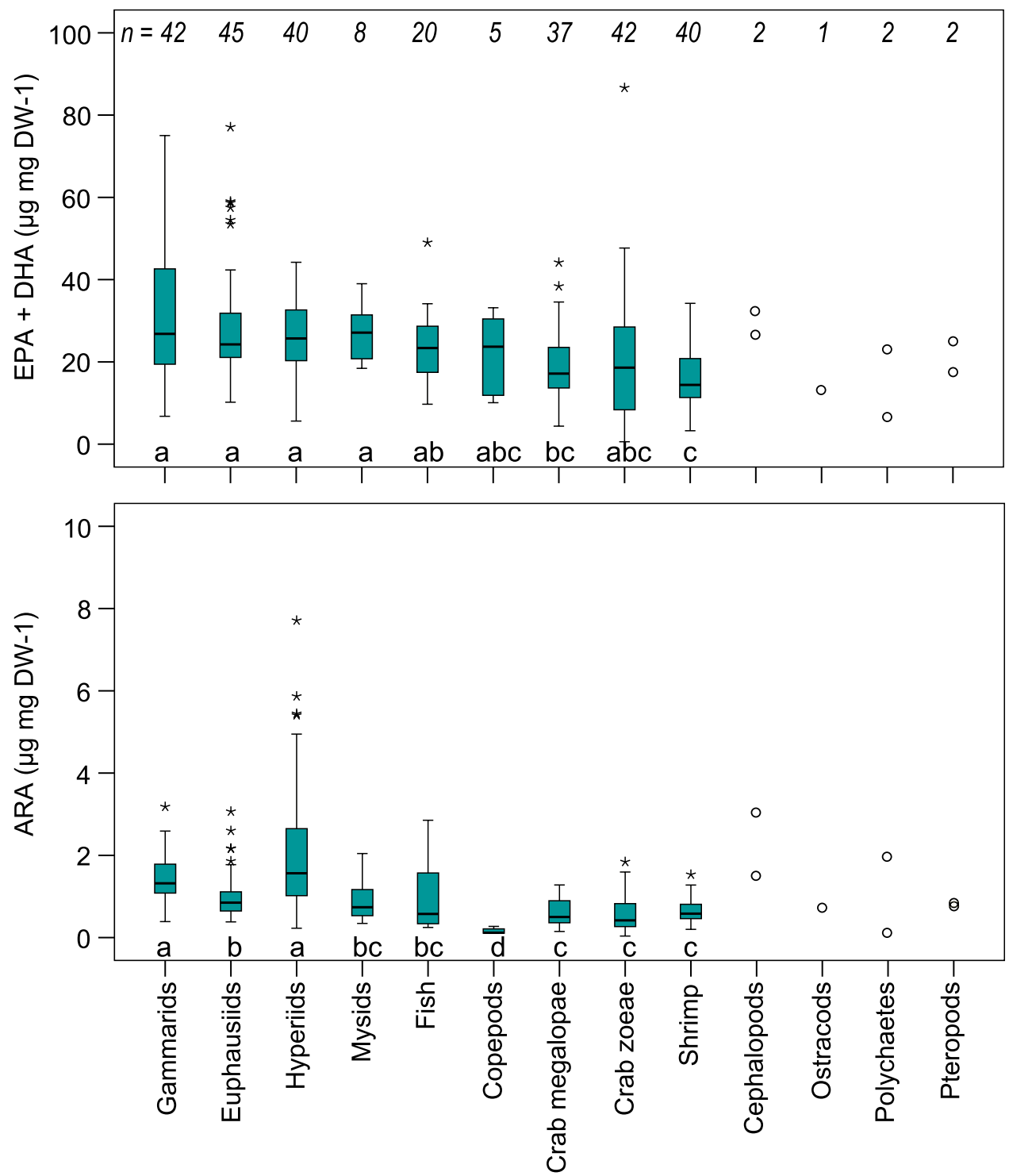

T. pacifica, and E. pacifica did not. In most taxa, we did not separate life stages, and that potentially confounded seasonal differences as there may be dietary shifts, e.g., increased carnivory with age. Yamada et al. (2016) found differences in both lipid content and composition among life stages and seasons of copepods in the western North Pacific, and several studies in polar regions have found strong seasonality in lipids (Kattner et al. 1994; Mayzaud et al. 2011). However, consistent with our results, Costalago et al. (2020) found that season and region had statistically significant but minor effects on zooplankton fatty acid composition in the northern Salish Sea. Similarly, salmon prey taxa (juvenile fish and pelagic invertebrates) from coastal Washington differed in their fatty acid composition but there was little difference when comparing May and June samples (Daly et al. 2010).

Feeding experiments demonstrate the incorporation of diatom and dinoflagellate fatty acid biomarkers into Calanus spp. tissues, indicating that fatty acids can be used as biomarkers to investigate zooplankton diets (Graeve et al. 1994). In our data, crab larvae, euphausiids, and copepods were rich in diatom biomarkers, which is consistent with herbivory and direct reliance on primary production. The high DHA/ EPA ratios in copepods could also indicate high consumption of flagellates (including dinoflagellates); however, copepods only had a low proportion of another flagellate marker

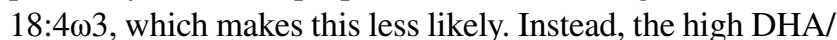
EPA ratio in copepods could be due to preferential retention of DHA over EPA, and thus be less affected by diet than the $\mathrm{C}_{16}$ and $\mathrm{C}_{18}$ PUFAs characteristic of diatoms. Even the carnivorous zooplankton taxa had $>1 \%$ diatom biomarkers, further indicating the importance of diatoms as a basal resource and demonstrating how these biomarkers transfer up the food chain. Bacterial fatty acids (BAFA) contributed $0.2-5.4 \%$ of zooplankton total fatty acids, with the highest values in 

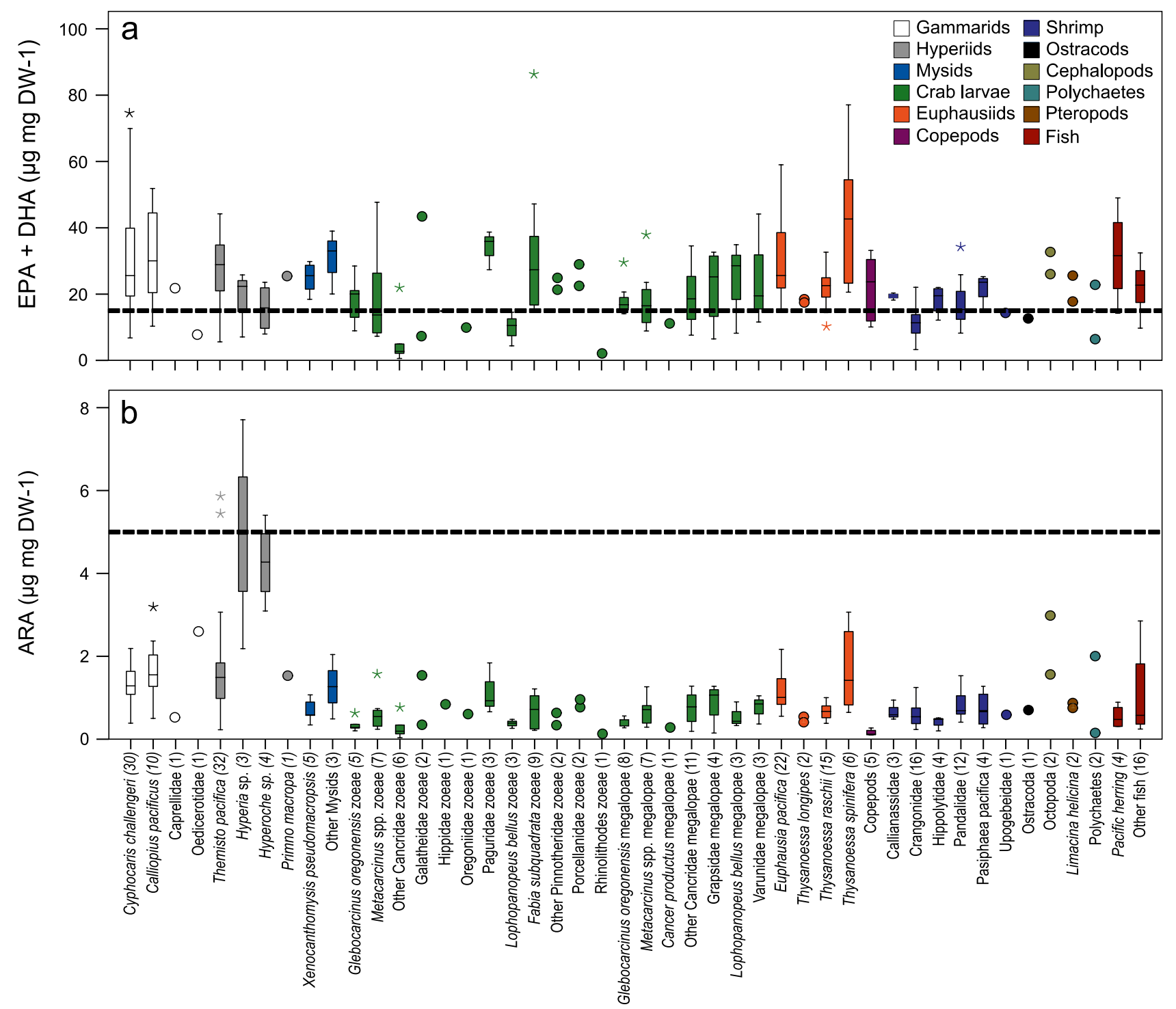

Fig. 5 a EPA+DHA and b ARA content $\left(\mu \mathrm{g} \mathrm{mg} \mathrm{DW}{ }^{-1}\right)$ in species (or families) of zooplankton and ichthyoplankton from Puget Sound and adjacent waters of northern Washington. Number of samples $(n)$ in brackets after taxon name. Box and whisker plots as described in Fig. 3. The dashed lines correspond to minimum nutritional requirements of Atlantic salmon and rainbow trout proposed by FAO hyperiid amphipods, shrimp, and mysids. BAFA are a biomarker for feeding on bacteria (or bacterivorous protozoans), which may be attached to detritus that can originate both from autochthonous and allochthonous sources (Ederington et al. 1995; Canuel 2001). Hyperiid amphipods are carnivo-

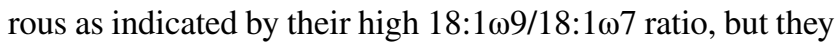
seem to prey on taxa that rely more on the detrital food web than do other carnivorous taxa. Shrimp had the second lowest carnivory index and the lowest contribution of DIFA, which together with high BAFA could indicate feeding on detritus. Based on gut content analyses, Pandalidae shrimp larvae are omnivorous, and they may feed on phytoplankton, zooplankton, and ciliates (Ariza and Ouellet 2009). Detritus and ciliates, together with phytoplankton and zooplankton, have also been found in the guts of mysids (Viherluoto et al. 2000). Only a low proportion of the long-chain SAFA 22:0 was found in zooplankton while 24:0, 26:0, and 28:0 were not detected, indicating that significant direct contribution of terrestrial organic matter to zooplankton production in Puget Sound was unlikely.

We found very high values of the carnivory index 18:1 $\omega 9 / 18: 1 \omega 7$ in gammarid amphipods, and especially in $C$. challengeri. Yamada and Ikeda (2003) suggested that based on their metabolic rates and chemical composition $C$. challengeri in western subarctic Pacific Ocean are opportunistic carnivores that may also feed on zooplankton carcasses. Similar 
to our results, a high proportion of 18:1 $\omega 9$ was also found in C. challengeri in the nearby Strait of Georgia (Costalago et al. 2020). 18:1 $\omega 9$ is characteristic for amphipods both in marine and freshwater environments (Graeve et al. 2001; Daly et al. 2010; Salonen et al. 2019), but it is unclear whether amphipods accumulate 18:1 $\omega 9$ from their prey (e.g., copepods) and/ or synthesize it de novo.

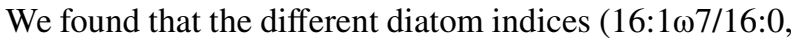
DIFA, DHA/EPA) correlated, both in the whole dataset as well as within the broad taxonomic groups. Our findings suggest that these are robust indices of diatom-based diets across broad taxonomic groups. In general, the values for 16:107/16:0 were rather low in our data; values $>1$ were only detected in two samples of Fabia subquadrata. Previ-

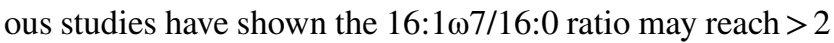
in herbivores and carnivores that depend on a diatom-based food chain (Cripps et al. 1999; Auel et al. 2002). However, PUFA indicative of diatoms (DIFA) reached $>10 \%$ in some crab larvae, particularly in April-June, consistent with the spring diatom peak in Puget Sound. It is likely that crab zoeae progress to a more carnivorous diet as they age, which may explain their seasonal change in FAs. The phytoplankton community in Puget Sound is typically dominated by diatoms year-round. This was especially true in 2017 when dinoflagellates were scarce (PSEMP 2019). The most common diatom genera were Chaetoceros, Skeletonema, and Thalassiosira; genera in which 16:167 may vary from 10 to $50 \%$ of total FA (Jonasdottir 2019). The consistently low
Fig. 7 EPA + DHA (a, c, and e) and ARA (b, d, and f) content in the amphipods Cyphocaris challengeri and Themisto pacifica (a and b), Cancridae crab larvae (c and d), and the euphausiid Euphausia pacifica (e and f) in spring (March-April), summer (May-July), and fall (August-October). Number of samples $(n)$ in brackets below season. Box and whisker plots as described in Fig. 3. Significant within taxa seasonal differences in pair-wise comparisons are denoted with different letters

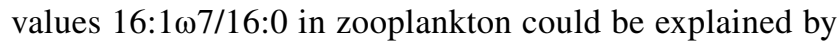
the diatom community consisting of taxa with low $16: 1 \omega 7$ content.

With a consistently high contribution of diatoms in the phytoplankton community, it is not surprising that there was little seasonal variation in zooplankton fatty acid composition. In general, we found that the planktonic food web in Puget Sound was highly supported by diatoms, with microbial/detrital food sources important in a few taxa, e.g., shrimp. The higher reliance on the microbial/detrital pathway correlated with lower EFA content in shrimp. Thus, our first hypothesis was supported as taxon-specific differences in fatty acid composition were linked to feeding strategies of zooplankton.

Estuarine habitats are often highly productive, and serve as important nursery and feeding areas for juvenile salmonids during their migration to the open waters of the Pacific Ocean (Simenstad et al. 1982). Prey selection by fishes is influenced by size, morphology, pigmentation, evasiveness, and availability, but the role of selection based on prey

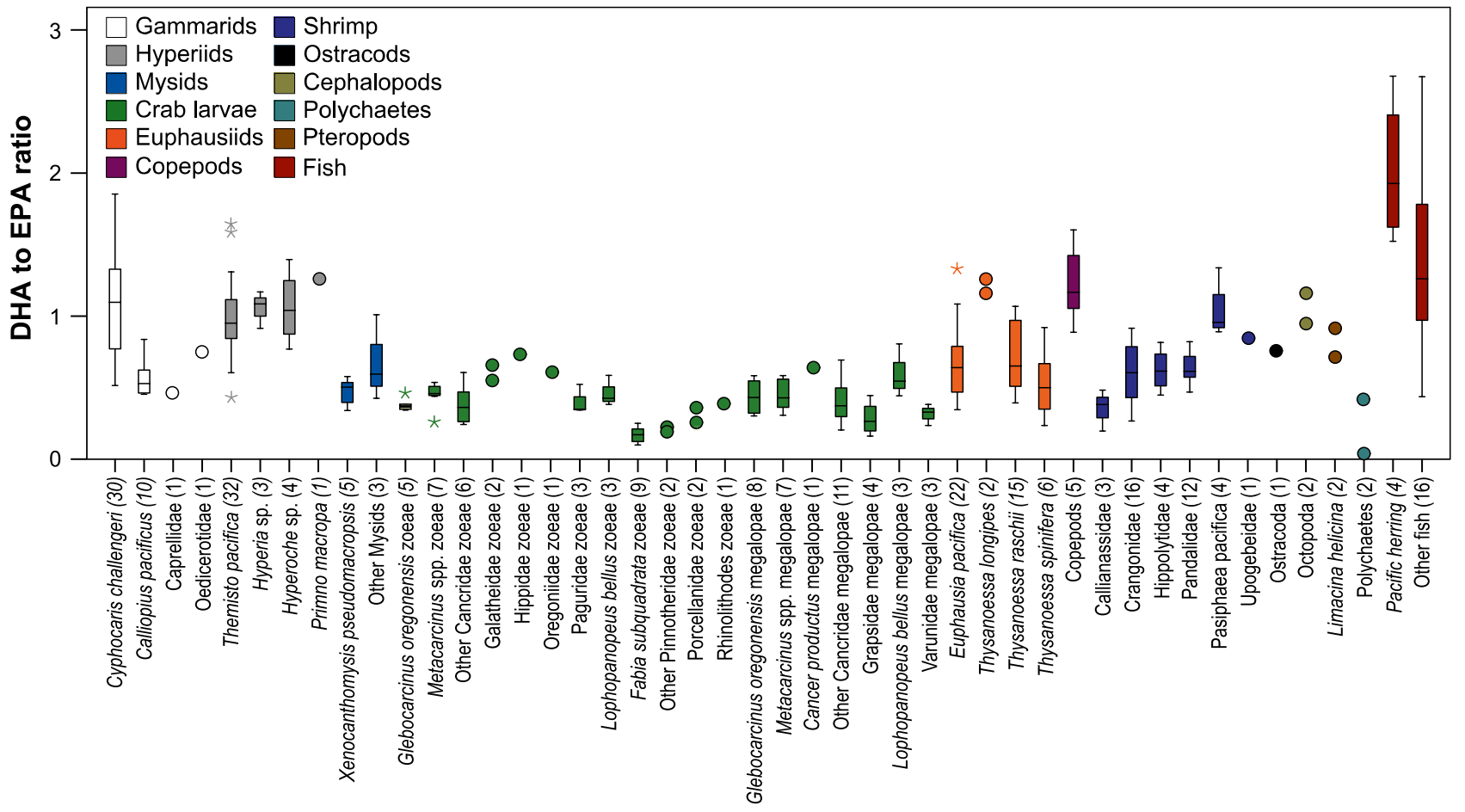

Fig. 6 DHA to EPA ratio in species (or families) of zooplankton and ichthyoplankton from Puget Sound and adjacent waters of northern Washington. Number of samples $(n)$ in brackets after taxon name. Box and whisker plots as described in Fig. 3 
$E P A+D H A$
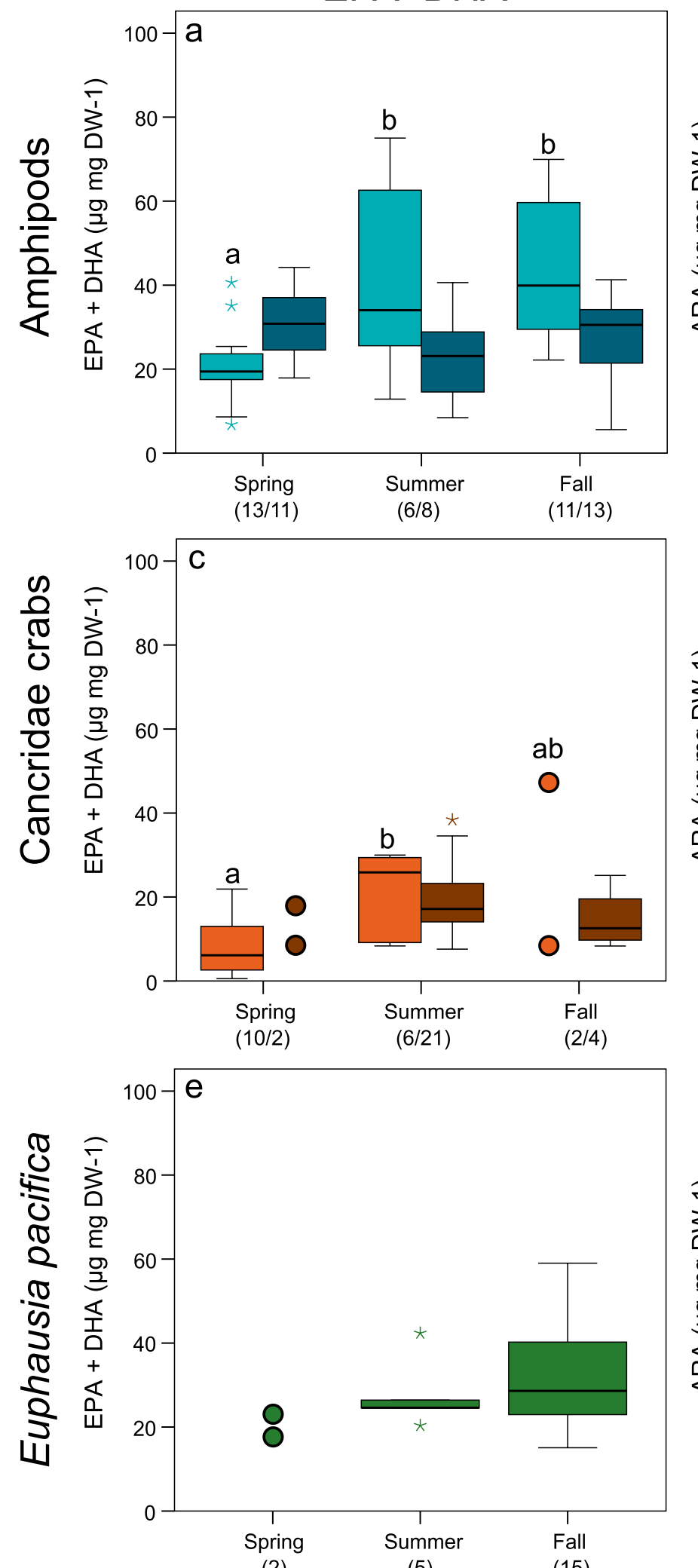

(2)

(5)

(15)
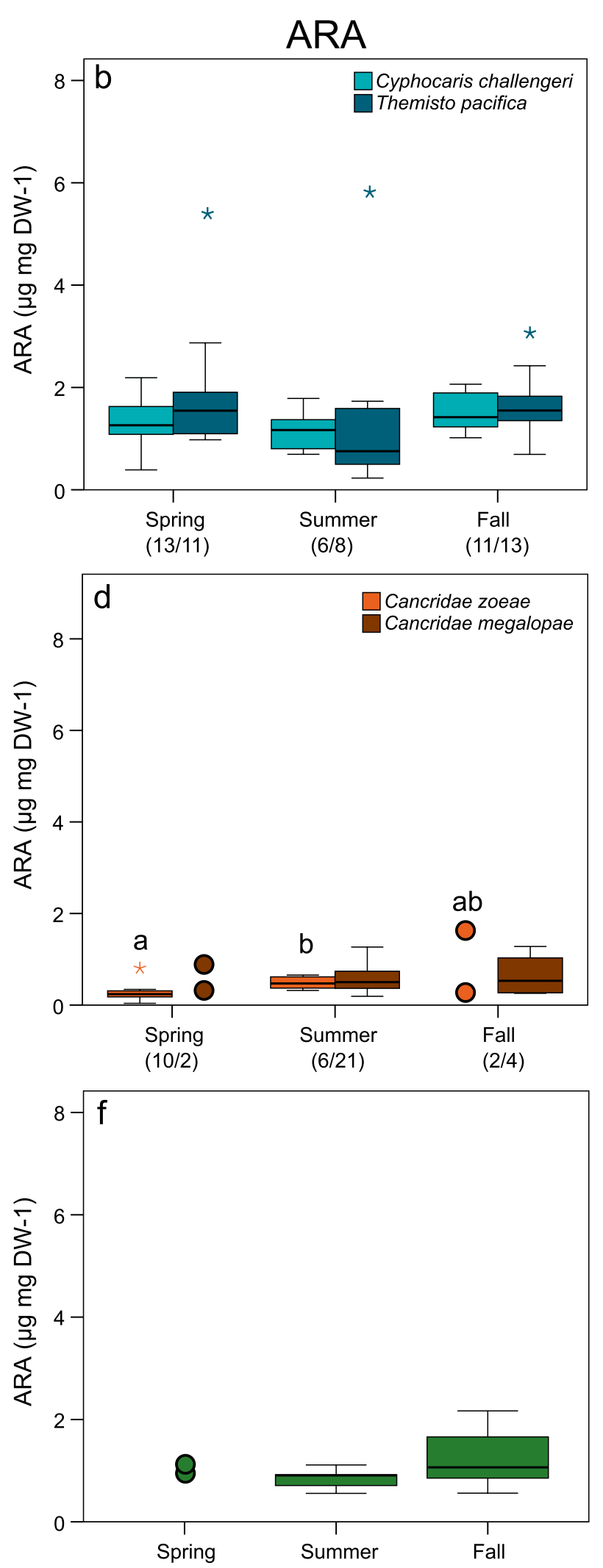

(2)

(5)

(15) 
quality is poorly understood. Juvenile coho and Chinook salmon prey selectively on large and pigmented prey items such as hyperiid amphipods, euphausiids, crab megalopae, and fish (Schabetsberger et al. 2003). Our results indicate that amphipods (both gammarids and hyperiids) together with larval/juvenile fish, mysids, euphausiids, crab larvae, and cephalopods are a good source of EFAs in juvenile salmon diets. Crab larvae are abundant in Puget Sound, and are an important prey source for juvenile salmonids, comprising up to $75 \%$ of Chinook salmon diets in Puget Sound in early summer (Duffy et al. 2010). High consumption of crab larvae in May-July has been associated with high growth rate and survival in juvenile Puget Sound Chinook salmon (Beauchamp and Duffy 2011). Our fatty acid composition data indicate that Puget Sound crab larvae are highly reliant on diatoms, which establishes an important link between diatom production and juvenile salmon growth during their critical growth period in early summer. We also found that shrimp and copepods are lower sources of EFAs in Puget Sound, although for copepods this may be partly due to timing of the sampling and that we did not sample many of the late-stage Calanus that accumulate lipids for diapause. In the northern California Current, juvenile Chinook salmon exhibit negative selectivity for larval stages of the bay ghost shrimp (Neotrypaea californiensis) and small copepods (Schabetsberger et al. 2003). Furthermore, Fraser River Sockeye salmon juveniles select euphausiids, amphipods, decapods, terrestrial insects, fish, eggs, and cumacean prey, but not copepods (Price et al. 2013). Similar to EFA, the total FA content was highest in the gammarid amphipods, and especially in $C$. challengeri. Previous studies have found that $C$. challengeri has high lipid/fatty acid content in nearby waters of British Columbia as well (Sargent and Lee 1975; Costalago et al. 2020). Thus, it seems that salmon select high-quality prey taxa when they are available, but whether the selection is based on the food quality or dependent on other factors such as size or prey behavior remains to be explored in controlled feeding trials.

Daly et al. (2010) studied the fatty acid composition of salmon prey taxa along the coast of Washington during the summer upwelling period and found that juvenile fish contained the highest amount of EFA (ARA + EPA + DHA mg $\mathrm{g} \mathrm{WW}^{-1}$ ). Of the invertebrates, Metacarcinus magister (formerly Cancer magister) larvae were the only ones measured with comparable DHA content to fish (Daly et al. 2010). The hyperiid amphipod Primno macropa and gammarid amphipod Atylus tridens had similar total EFA content to crab larvae, but significantly lower DHA content. This is somewhat different from our results where hyperiids (primarily Themisto pacifica) and gammarids ( $C$. challengeri) were richer in DHA (and total EFA) than crab larvae.

The ratios of EFAs, in addition to absolute amounts, are important for fish growth and survival (Sargent et al. 1999).
All of the invertebrate prey in salmon diets from coastal Washington contained DHA:EPA ratios from 0.19 to 0.75 , with the highest ratios observed in crab larvae and euphausiids (Daly et al. 2010). In contrast, we found that crab megalopae and zoeae had lower DHA:EPA ratios $(0.4 \pm 0.2)$ than the other invertebrate taxa (0.6-1.2), similar to crab larvae in the Strait of Georgia (Costalago et al. 2020). In previous studies (Daly et al. 2010; Costalago et al. 2020) and in our study, prey fish exhibited higher DHA:EPA ratios than invertebrates: $1.0 \pm 0.3$ for juvenile fish in Daly et al. (2010), 1.85 for larval fish in Costalago et al. (2020), and 1.5 \pm 0.6 for larval fish in our study. Similar to these fish, juvenile salmon have higher DHA:EPA ratios than invertebrates (on average > 1.5) (Mjaavatten et al. 1998; Daly et al. 2010; Litz et al. 2017a) potentially indicating higher demand for DHA than EPA. Litz et al. (2017b) found no difference in growth of Chinook salmon over dietary DHA:EPA ratios of 0.6-1.5; however, more studies are needed to elucidate the effects of different EFAs and their ratios on juvenile salmon performance. The comparison between our study and that of Daly et al. (2010) reveals dissimilarities in the potential prey quality between Puget Sound and coastal Washington, which could help explain differences in salmon performance between these areas.

We compared the EFA content of Puget Sound zooplankton and ichthyoplankton to the minimum requirements for optimal growth of Atlantic salmon and rainbow trout proposed by FAO. However, FAO does not provide values for the wild salmonid species that are native to Puget Sound, and the threshold values are based on aquaculture studies, so they may not be entirely representative of requirements of fish living in the more complex and dynamic natural environments. Despite these caveats, these values may provide insights on the approximate amounts of EFA needed by native juvenile salmonids. The EPA + DHA threshold (10-15 $\left.\mu \mathrm{g} \mathrm{mg} \mathrm{DW}^{-1}\right)$ was exceeded in most of the zooplankton and ichthyoplankton taxa we analyzed, excluding a few crab larvae and Crangonidae shrimp. This suggests that juvenile fish that feed opportunistically on multiple taxa would easily gain enough EPA + DHA from their diet in Puget Sound. The threshold for ARA $\left(5 \mu \mathrm{g} \mathrm{m} \mathrm{DW}^{-1}\right)$, on the other hand, was not met by most taxa, as only some samples of the hyperiid amphipods Hyperia and Hyperoche exceeded this threshold. However, a study on Chinook salmon juveniles found that diets lacking ARA completely (but offering $10-15 \%$ other $\omega$-6 PUFA) did not suppress growth or survival of fish (Grant et al. 2008), indicating that the threshold for ARA likely is species-specific and may depend on the availability of other $\omega-6$ PUFA. The role of ARA (and other $\omega$-6 PUFA) in fish nutrition has been much less extensively studied than the $\omega$-3 PUFA EPA and DHA, although ARA is recognized as a crucial eicosanoid precursor in 
fish tissues (Bell and Sargent 2003). The ratio of ARA to EPA + DHA (or $\omega-6$ to $\omega-3$ PUFA) may also be important for fish performance, further complicating the estimation of threshold values, even for aquaculture systems.

Food quantity and quality influence fish performance concurrently and separating their effects can be challenging. Juvenile salmon survival in Southeast Alaska was linked with stomach fullness (food quantity) rather than prey energy density (food quality) (Weitkamp and Sturdevant 2008). Similarly, in Puget Sound, juvenile salmon growth was linked to food supply, while composite energy density of diets in July varied very little and was not linked to survival (Beauchamp and Duffy 2011). On the other hand, using a bioenergetics model, Ballantyne et al. (2003) estimated that the growth of juvenile Sockeye salmon in Lake Washington is potentially limited by low DHA in their primary zooplankton prey. Fatty acid as a component of prey quality has rarely been taken into account in field studies, likely because detailed, species-specific information on fatty acid composition of prey has not been previously available. Fatty acid composition is not the only factor determining prey quality; however, considering it in a complementary fashion with, e.g., prey quantity, energy density, costs of prey capture, and consumption may provide important insights when studying fish performance in the field.

Zooplankton play a pivotal role in transferring phytoplankton-produced EFA to fish, and long-term changes in zooplankton biomass or community composition have been suggested as possible controls on the low salmon survival in Puget Sound (Keister et al. 2011; Hertz et al. 2016). Our dataset that encompasses $\sim 60$ zooplankton taxa that juvenile salmon and numerous other fish species prey upon provides baseline information on the nutritional quality of key prey and trophic relationships in Puget Sound that can be used in modeling studies. Similar to taxon-specific differences in zooplankton energy density in the Salish Sea discovered by Weil et al. (2020), we found differences in EFA content among broad salmon prey groups and even closely related species. Thus, the nutritional quality both in terms of EFA content and energy density of zooplankton prey for higher trophic level consumers varies, indicating that changes in zooplankton community composition may have far-reaching consequences for the whole food web. In the long term, the results of this study could also lead to more sensitive indicators of salmon survival, which incorporate both zooplankton species composition and the fatty acid composition of key prey taxa.

Supplementary Information The online version contains supplementary material available at https://doi.org/10.1007/s12237-021-00973-8.

Acknowledgements We would like to thank King County, the Nisqually Indian Tribe, the Lummi Nation, the Tulalip Tribe, Kwiáht, the Port Gamble S'Klallam Tribe, NOAA, WDFW, and Anna McLaskey for collecting the zooplankton lipid samples; BethElLee Herrmann for the assistance in sorting taxa and managing databases; Songlin Wang, Emily Anzalone, and Sean Yeung for the laboratory EFA analysis; and Jussi Vesamäki and Ville Vesakoski for their help with data processing. Any use of trade, firm, or product names is for descriptive purposes only and does not imply endorsement by the U.S. Government.

Funding Open access funding provided by University of Eastern Finland (UEF) including Kuopio University Hospital. The study was funded by Long Live the Kings as part of the Salish Sea Marine Survival Project. (contribution \#57) MH was also supported by an Academy of Finland grant (\#315163).

\section{Declarations}

Conflict of Interest The authors declare no competing interests.

Open Access This article is licensed under a Creative Commons Attribution 4.0 International License, which permits use, sharing, adaptation, distribution and reproduction in any medium or format, as long as you give appropriate credit to the original author(s) and the source, provide a link to the Creative Commons licence, and indicate if changes were made. The images or other third party material in this article are included in the article's Creative Commons licence, unless indicated otherwise in a credit line to the material. If material is not included in the article's Creative Commons licence and your intended use is not permitted by statutory regulation or exceeds the permitted use, you will need to obtain permission directly from the copyright holder. To view a copy of this licence, visit http://creativecommons.org/licenses/by/4.0/.

\section{References}

Ariza, P., and P. Ouellet. 2009. Diet components of northern shrimp Pandalus borealis first stage larvae in the Northwest Gulf of St. Lawrence. Journal of Crustacean Biology 29: 532-543.

Auel, H., M. Harjes, R. Da Rocha, D. Stübing, and W. Hagen. 2002. Lipid biomarkers indicate different ecological niches and trophic relationships of the Arctic hyperiid amphipods Themisto abyssorum and T. libellula. Polar Biology 25: 374-383.

Ballantyne, A.P., M.T. Brett, and D.E. Schindler. 2003. The importance of dietary phosphorus and highly unsaturated fatty acids for sockeye (Oncorhynchus nerka) growth in Lake Washington a bioenergetics approach. Canadian Journal of Fisheries and Aquatic Sciences 60: 12-22.

Barry, K.J., and J.T. Trushenski. 2020. Reevaluating polyunsaturated fatty acid essentiality in rainbow trout. North American Journal of Aquaculture 82: 251-264.

Beauchamp, D. A., and Duffy, E. J. 2011. Stage-specific growth and survival during early marine life of Puget Sound Chinook salmon in the context of temporal-spatial environmental conditions and trophic interactions. Final report to the Pacific Salmon Commission, Pacific Salmon Commission.

Bell, J.G., and J.R. Sargent. 2003. Arachidonic acid in aquaculture feeds: Current status and future opportunities. Aquaculture 218: 491-499.

Bell, J.G., D.R. Tocher, B.M. Farndale, D.I. Cox, R.W. McKinney, and J.R. Sargent. 1997. The effect of dietary lipid on polyunsaturated fatty acid metabolism in Atlantic salmon (Salmo salar) undergoing parr-smolt transformation. Lipids 32: 515-525.

Bell, M.V., J.R. Dick, T.R. Anderson, and D.W. Pond. 2007. Application of liposome and stable isotope tracer techniques to study polyunsaturated fatty acid biosynthesis in marine zooplankton. Journal of Plankton Research 29: 417-422. 
Budge, S.M., S.J. Iverson, W.D. Bowen, and R.G. Ackman. 2002. Among- and within-species variability in fatty acid signatures of marine fish and invertebrates on the Scotian Shelf, Georges Bank, and southern Gulf of St. Lawrence. Canadian Journal of Fisheries and Aquatic Sciences 59: 886-898.

Budge, S.M., S.N. Penney, and S.P. Lall. 2012. Estimating diets of Atlantic salmon (Salmo salar) using fatty acid signature analyses; validation with controlled feeding studies. Canadian Journal of Fisheries and Aquatic Sciences 69: 1033-1046.

Canuel, E.A. 2001. Relations between river flow, primary production and fatty acid composition of particulate organic matter in San Francisco and Chesapeake Bays: A multivariate approach. Organic Geochemistry 32: 563-583.

Costalago, D., I. Forster, N. Nemcek, C. Neville, R.I. Perry, K. Young, and B.P. Hunt. 2020. Seasonal and spatial dynamics of the planktonic trophic biomarkers in the Strait of Georgia (northeast Pacific) and implications for fish. Scientific Reports 10: 1-12.

Coutteau, P., I. Geurden, M.R. Camara, P. Bergot, and P. Sorgeloos. 1997. Review on the dietary effects of phospholipids in fish and crustacean larviculture. Aquaculture 155: 149-164.

Cripps, G.C., J.L. Watkins, H.J. Hill, and A. Atkinson. 1999. Fatty acid content of Antarctic krill Euphausia superba at South Georgia related to regional populations and variations in diet. Marine Ecology Progress Series 181: 177-188.

Dalsgaard, J., M.S. John, G. Kattner, D. Müller-Navarra, and W. Hagen. 2003. Fatty acid trophic markers in the pelagic marine environment. Advances in Marine Biology 46: 225-340.

Daly, E.A., C.E. Benkwitt, R.D. Brodeur, M.N. Litz, and L.A. Copeman. 2010. Fatty acid profiles of juvenile salmon indicate prey selection strategies in coastal marine waters. Marine Biology 157: 1975-1987.

Duffy, E.J., D.A. Beauchamp, R.M. Sweeting, R.J. Beamish, and J.S. Brennan. 2010. Ontogenetic diet shifts of juvenile Chinook salmon in nearshore and offshore habitats of Puget Sound. Transactions of the American Fisheries Society 139: 803-823.

Ederington, M.C., G.B. McManus, and H.R. Harvey. 1995. Trophic transfer of fatty acids, sterols, and a triterpenoid alcohol between bacteria, a ciliate, and the copepod Acartia tonsa. Limnology and Oceanography 40: 860-867.

El-Sabaawi, R., J.F. Dower, M. Kainz, and A. Mazumder. 2009. Characterizing dietary variability and trophic positions of coastal calanoid copepods: Insight from stable isotopes and fatty acids. Marine Biology 156: 225-237.

Falk-Petersen, S., W. Hagen, G. Kattner, A. Clarke, and J. Sargent. 2000. Lipids, trophic relationships, and biodiversity in Arctic and Antarctic krill. Canadian Journal of Fisheries and Aquatic Sciences 57: 178-191.

FAO. 2020a. Summary of dietary nutrient requirement and utilization of Atlantic salmon, Salmo salar http://www.fao.org/fileadmin/ user_upload/affris/docs/Atlantic_Salmon/table_2.htm, accessed 15.6.2020

FAO. 2020b. Summary of dietary nutrient requirement and utilization of rainbow trout, Oncorhychus mykiss. http://www.fao.org/ fileadmin/user_upload/affris/docs/Trout/English/table_2.htm, accessed 15.6.2020

Folch, J., M. Lees, and S.G.H. Sloane. 1957. A simple method for the isolation and purification of total lipids from animal tissues. Journal of Biological Chemistry 226: 497-509.

Fraser, A.J., J.R. Sargent, J.C. Gamble, and D.D. Seaton. 1989. Formation and transfer of fatty acids in an enclosed marine food chain comprising phytoplankton, zooplankton and herring (Clupea harengus L.) larvae. Marine Chemistry 27: 1-18.

Galloway, A.W., S.J. Taipale, M. Hiltunen, E. Peltomaa, U. Strandberg, M.T. Brett, and P. Kankaala. 2014. Diet-specific biomarkers show that high-quality phytoplankton fuels herbivorous zooplankton in large boreal lakes. Freshwater Biology 59: 1902-1915.
Gamble, M. M. 2016. Size-selective mortality and environmental factors affecting early marine growth during early marine life stages of sub-yearling Chinook salmon in Puget Sound, Washington (Doctoral dissertation).

Glencross, B.D. 2009. Exploring the nutritional demand for essential fatty acids by aquaculture species. Reviews in Aquaculture 1: 71-124.

Graeve, M., G. Kattner, and W. Hagen. 1994. Diet-induced changes in the fatty acid composition of Arctic herbivorous copepods: Experimental evidence of trophic. Journal of Experimental Marinc Biology and Ecology 182: 97-110.

Graeve, M., P. Dauby, and Y. Scailteur. 2001. Combined lipid, fatty acid and digestive tract content analyses: A penetrating approach to estimate feeding modes of Antarctic amphipods. Polar Biology 24: 853-862.

Grant, A.A., D. Baker, D.A. Higgs, C.J. Brauner, J.G. Richards, S.K. Balfry, and P.M. Schulte. 2008. Effects of dietary canola oil level on growth, fatty acid composition and osmoregulatory ability of juvenile fall chinook salmon (Oncorhynchus tshawytscha). Aquaculture 277: 303-312.

Happel, A., L. Stratton, C. Kolb, C. Hays, J. Rinchard, and S. Czesny. 2016. Evaluating quantitative fatty acid signature analysis (QFASA) in fish using controlled feeding experiments. Canadian Journal of Fisheries and Aquatic Sciences 73: 1222-1229.

Hertz, E., M. Trudel, S. Tucker, T.D. Beacham, C. Parken, D. Mackas, and A. Mazumder. 2016. Influences of ocean conditions and feeding ecology on the survival of juvenile Chinook salmon (Oncorhynchus tshawytscha). Fisheries Oceanography 25: 407-419.

Hiltunen, M., U. Strandberg, M. Keinänen, S. Taipale, and P. Kankaala. 2014. Distinctive lipid composition of the copepod Limnocalanus macrurus with a high abundance of polyunsaturated fatty acids. Lipids 49: 919-932.

Hiltunen, M., U. Strandberg, S.J. Taipale, and P. Kankaala. 2015. Taxonomic identity and phytoplankton diet affect fatty acid composition of zooplankton in large lakes with differing dissolved organic carbon concentration. Limnology and Oceanography 60: 303-317.

Hiltunen, M., Strandberg, U., Keister, J., Beauchamp, D., and Brett, M.T. 2019a. Fatty acid composition of zooplankton prey for juvenile salmonids in Puget Sound. Salish Sea Marine Survival Project Technical Report, https://marinesurvivalproject.com.

Hiltunen, M., E. Peltomaa, M.T. Brett, S.L. Aalto, U. Strandberg, J. Oudenampsen, L.M. Burgwal, and S.J. Taipale. 2019b. Terrestrial organic matter quantity or decomposition state does not compensate for its poor nutritional quality for Daphnia. Freshwater Biology 64: 1769-1786.

Jónasdóttir, S.H. 2019. Fatty acid profiles and production in marine phytoplankton. Marine Drugs 17: 151.

Kaneda, T. 1991. Iso- and anteiso-fatty acids in bacteria: Biosynthesis, function, and taxonomic significance. Microbiology and Molecular Biology Reviews 55: 288-302.

Kattner, G., M. Graeve, and W. Hagen. 1994. Ontogenetic and seasonal changes in lipid and fatty acid/alcohol compositions of the dominant Antarctic copepods Calanus propinquus, Calanoides acutus and Rhincalanus gigas. Marine Biology 118: 637-644.

Keister, J.E., E. Di Lorenzo, C.A. Morgan, V. Combes, and W.T. Peterson. 2011. Zooplankton species composition is linked to ocean transport in the Northern California Current. Global Change Biology 17: 2498-2511.

Keister, J. E., Winans, A., Herrmann, B. 2017. Salish Sea Marine Survival Project: Zooplankton Monitoring Program 2014-2015 Final Report. Salish Sea Marine Survival Project Technical Report, https://marinesurvivalproject.com.

Kendall, N.W., G.W. Marston, and M.M. Klungle. 2017. Declining patterns of Pacific Northwest steelhead trout (Oncorhynchus mykiss) adult abundance and smolt survival in the ocean. Canadian Journal of Fisheries and Aquatic Sciences 74: 1275-1290. 
Lee, R.F., W. Hagen, and G. Kattner. 2006. Lipid storage in marine zooplankton. Marine Ecology Progress Series 307: 273-306.

Litz, M.N., J.A. Miller, L.A. Copeman, D.J. Teel, L.A. Weitkamp, E.A. Daly, and A.M. Claiborne. 2017a. Ontogenetic shifts in the diets of juvenile Chinook salmon: New insight from stable isotopes and fatty acids. Environmental Biology of Fishes 100: 337-360.

Litz, M.N., J.A. Miller, L.A. Copeman, and T.P. Hurst. 2017b. Effects of dietary fatty acids on juvenile salmon growth, biochemistry, and aerobic performance: A laboratory rearing experiment. Journal of Experimental Marine Biology and Ecology 494: 20-31.

Mayzaud, P., S. Lacombre, and M. Boutoute. 2011. Seasonal and growth stage changes in lipid and fatty acid composition in the multigeneration copepod Drepanopus pectinatus from Iles Kerguelen. Antarctic Science 23: 3.

Mjaavatten, O., C.D. Levings, and P. Poon. 1998. Variation in the fatty acid composition of juvenile Chinook and coho salmon from Fraser river estuary determined by multivariate analysis; role of environment and genetic origin. Comparative Biochemistry and Physiology Part b: Biochemistry and Molecular Biology 120: 291-309.

Moore, S.K., N.J. Mantua, J.A. Newton, M. Kawase, M.J. Warner, and J.P. Kellogg. 2008. A descriptive analysis of temporal and spatial patterns of variability in Puget Sound oceanographic properties. Estuarine, Coastal and Shelf Science 80: 545-554.

Nghia, T.T., M. Wille, S. Vandendriessche, Q.T. Vinh, and P. Sorgeloos. 2007. Influence of highly unsaturated fatty acids in live food on larviculture of mud crab Scylla paramamosain (Estampador 1949). Aquaculture Research 38: 1512-1528.

Paulsen, M., C. Clemmesen, and A.M. Malzahn. 2014. Essential fatty acid (docosahexaenoic acid, DHA) availability affects growth of larval herring in the field. Marine Biology 161: 239-244.

Persson, J., and T. Vrede. 2006. Polyunsaturated fatty acids in zooplankton: Variation due to taxonomy and trophic position. Freshwater Biology 51: 887-900.

Price, M.H., B.W. Glickman, and J.D. Reynolds. 2013. Prey selectivity of Fraser River sockeye salmon during early marine migration in British Columbia. Transactions of the American Fisheries Society 142: 1126-1133.

PSEMP Marine Waters Workgroup. 2019. Puget Sound marine waters: 2018 overview. S. K. Moore, R. Wold, B. Curry, K. Stark, J. Bos, P. Williams, N. Hamel, J. Apple, S. Kim, A. Brown, C. Krembs, and J. Newton, editors.

QGIS Development Team. 2016. QGIS Geographic Information System. Open Source Geospatial Foundation Project. http://qgis. osgeo.org

Ruff, C.P., J.H. Anderson, I.M. Kemp, N.W. Kendall, P.A. Mchugh, A. Velez-Espino, C.M. Greene, M. Trudel, A. Holt, K.E. Ryding, and K. Rawson. 2017. Salish Sea Chinook salmon exhibit weaker coherence in early marine survival trends than coastal populations. Fisheries Oceanography 26: 625-637.

Ruyter, B., C. Røsjø, O. Einen, and M.S. Thomassen. 2000. Essential fatty acids in Atlantic salmon: Effects of increasing dietary doses of n- 6 and n-3 fatty acids on growth, survival and fatty acid composition of liver, blood and carcass. Aquaculture Nutrition 6: 119-127.

Salonen, J.K., M. Hiltunen, K. Figueiredo, P. Paavilainen, T. Sinisalo, U. Strandberg, P. Kankaala, and J. Taskinen. 2019. Population structure, life cycle, and trophic niche of the glacial relict amphipod, Gammaracanthus lacustris, in a large boreal lake. Freshwater Biology 64: 2176-2188.
Sargent, J.R., and R.F. Lee. 1975. Biosynthesis of lipds in zooplankton from Saanich Inlet, British Columbia, Canada. Marine Biology 31: 15-23.

Sargent, J., G. Bell, L. McEvoy, D. Tocher, and A. Estevez. 1999. Recent developments in the essential fatty acid nutrition of fish. Aquaculture 177: 191-199.

Schabetsberger, R., C.A. Morgan, R.D. Brodeur, C.L. Potts, W.T. Peterson, and R.L. Emmett. 2003. Prey selectivity and diel feeding chronology of juvenile chinook (Oncorhynchus tshawytscha) and coho $(O$. kisutch) salmon in the Columbia River plume. Fisheries Oceanography 12: 523-540.

Simenstad, C. A., Fresh, K. L., and Salo, E. O. 1982. The role of Puget Sound and Washington coastal estuaries in the life history of Pacific salmon: an unappreciated function. In: Kennedy, V. S. (ed) Estuarine Comparisons, Proc 6th Biennial Int Estuarine Res Conf, Academic Press, pp. 343-364.

Stevens, C.J., D. Deibel, and C.C. Parrish. 2004. Species-specific differences in lipid composition and omnivory indices in Arctic copepods collected in deep water during autumn (North Water Polynya). Marine Biology 144: 905-915.

Strandberg, U., M. Hiltunen, S.J. Taipale, S. Yeung, and P. Kankaala. 2018. Planktivorous vendace (Coregonus albula) utilise algaederived fatty acids for biomass increase and lipid deposition. Ecology of Freshwater Fish 27: 533-541.

St John, M.A., and T. Lund. 1996. Lipid biomarkers: Linking the utilization of frontal plankton biomass to enhanced condition of juvenile North Sea cod. Marine Ecology Progress Series 131: 75-85.

Takeuchi, T., and T. Watanabe. 1982. Effects of various polyunsaturated fatty acids on growth and fatty acid compositions of rainbow trout Salmo gairdneri, coho salmon Oncorhynchus kisutch, and chum salmon Oncorhynchus keta. Bulletin of the Japanese Society of Scientific Fisheries 48: 1745-1752.

US Salish Sea Technical Team. 2012. Marine survival of salmon and steelhead in the Salish Sea: hypotheses and preliminary research recommendations for Puget Sound. www.marinesurvivalproject. com

Weitkamp, L.A., and M.V. Sturdevant. 2008. Food habits and marine survival of juvenile Chinook and coho salmon from marine waters of Southeast Alaska. Fisheries Oceanography 17: 380-395.

Weil, J., W.D. Duguid, and F. Juanes. 2020. Fine-scale taxonomic and temporal variability in the energy density of invertebrate prey of juvenile Chinook salmon Oncorhynchus tshawytscha. Marine Ecology Progress Series 655: 185-198.

Viherluoto, M., H. Kuosa, J. Flinkman, and M. Viitasalo. 2000. Food utilisation of pelagic mysids, Mysis mixta and M. relicta, during their growing season in the northern Baltic Sea. Marine Biology 136: 553-559.

Yamada, Y., and T. Ikeda. 2003. Metabolism and chemical composition of four pelagic amphipods in the Oyashio region, western subarctic Pacific Ocean. Marine Ecology Progress Series 253: 233-241.

Yamada, Y., S. Nishida, M. Graeve, and G. Kattner. 2016. Lipid and fatty acid/alcohol compositions of the subarctic copepods Neocalanus cristatus and Eucalanus bungii from various depths in the Oyashio region, western North Pacific. Comparative Biochemistry and Physiology Part b: Biochemistry and Molecular Biology 198: $57-65$.

Zimmerman, M.S., J.R. Irvine, M. O’Neill, J.H. Anderson, C.M. Greene, J. Weinheimer, M. Trudel, and K. Rawson. 2015. Spatial and temporal patterns in smolt survival of wild and hatchery coho salmon in the Salish Sea. Marine and Coastal Fisheries 7: 116-134. 